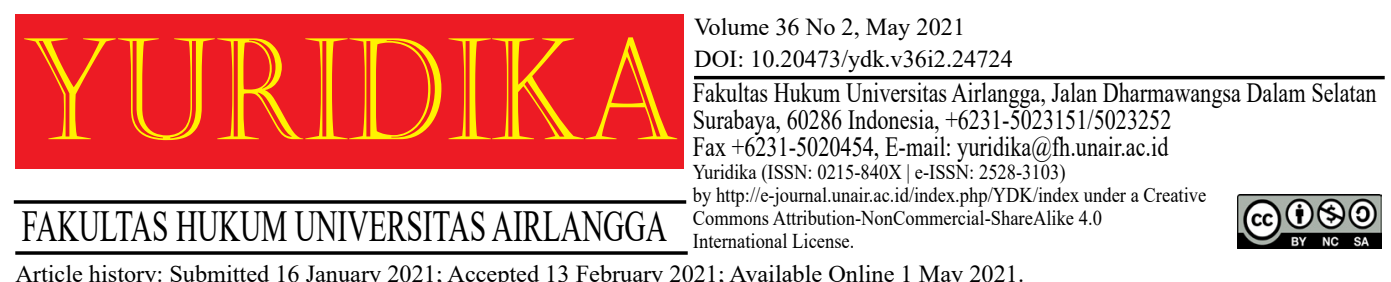

\title{
Disclosure of Information on Environmental Documents in Supporting the Role of Public Monitoring
}

\author{
I Made Gemet Dananjaya Suta, I Gusti Agung Mas Prabandari \\ and Ni Luh Gede Astariyani \\ danan.ade@gmail.com \\ Udayana University and Airlangga University
}

\begin{abstract}
The role of the community is very important in realizing the fulfillment of the right to a good and healthy environment for everyone as part of human rights. The lack of awareness of the disclosure of information on environmental documents to the public in conducting surveillance of activities or businesses that have an important impact on the environment is one of the many violations of environmental law that results in environmental damage and pollution. This paper seeks to examine the importance of information disclosure on environmental documents in supporting the role of community oversight of activities that have an important impact on the environment. The research method used is a normative legal research method with the statutory approach and conceptual approach. The conclusion of this paper discovered that disclosure of information on environmental documents is important as an effort to optimize the role of public monitoring. Environmental documents are used as a guide for detailed information related to compliance with the implementation of activity on its terms and obligations. This disclosure information must be seen as the implementation of the right to access information in support of the implementation of community responsibility for guaranteeing and fulfilling the rights of everyone to a good and healthy environment as a human right so that environmental damage and pollution from activities that are illegal and/or violate their environmental permits can be controlled and prevented.
\end{abstract}

Keywords: Disclosure Information; Environmental Document; Public Monitoring.

\section{Introduction}

The environment is something that cannot be separated from humans as living beings. The environment has a very important meaning for human life. Not only as a place to live but also as a provider of resources for humans to fulfill their needs in carrying out their lives. The use of the environment in the effort of humans to meet their needs is an important matter that needs attention. Utilization 
of the environment must be far forward-oriented, meaning that in the method or process of environmental use, it must pay attention to and consider the preservation of environmental functions, where its use is not only intended for the needs or interests of the present generation, but also the benefit of future generations.

The development of human life, especially in the fields of science and technology, certainly increases the human need for natural resources. Uncontrolled fulfillment of human needs and tend to take the name of development as the main purpose, have an impact on the exploration and utilization of natural resources that do not pay attention to the preservation of environmental functions that cause damage and pollution of the environment. Oftentimes, the importance of economic and social development becomes the reason for ignoring the sustainability factor of environmental function. Environmental problems due to damage and pollution are essential problems that must be handled comprehensively because they can threaten human survival. In the digital era today, environmental problems are one of the cases that concern not only national but the international community. With the rapid flow of information, especially regarding environmental conditions that are increasingly damaged and polluted, there has been much awareness arising about the importance of preserving environmental functions, both initiated by social movements and scientific studies that focus on preserving environmental functions such as development. environmentally friendly technology, environmental-based economic budgets, environmentally friendly new and renewable energy development, as well as legal studies and government policies related to environmental protection and supervision.

The right of every person to have a good and healthy living environment has been regulated in the Indonesian Constitution as part of human rights as stipulated in the mandate of Article 28H paragraph (1) of the Constitution of the Republic of Indonesia 1945 (hereinafter referred to as UUD NRI 1945) and further emphasized also in Article 9 paragraph (3) of Law Number 39 of 1999 concerning Human Rights. Recognition of this right implies that the responsibility to protect the environment is the duty of everyone, including the state government as the holder of power. The government is obliged to guarantee human rights to the environment through 
policies and programs that protect to prevent environmental damage and provide a supervision system aimed at preserving environmental functions.

With the enactment of Law Number 32 of 2009 concerning Environmental Protection and Supervision (hereinafter referred to as UUPPLH), the Government intends to carry out a more appropriate reform in protecting and preserving ecosystems as part of the environment. In terms of overcoming environmental problems, it will not work well if it is considered the sole responsibility of the government. In this case, the community plays an important role in fighting for and enforcing their rights to a good and healthy environment and especially for the next generation. This is because everyone has the same rights and obligations to play a role in environmental protection and supervision or what is commonly known as participatory right or the right to participate. ${ }^{1}$ In ensuring the fulfillment and protection of the right to the environment, the UUPPLH regulates the recognition of several rights to the environment, namely: ${ }^{2}$ (1) the right to a good and healthy environment; (2) the right to environmental education; (3) the right to access information; (4) the right to access to participation; (5) the right to submit proposals or objections to an activity plan that may have an impact on the environment; (6) the right to report an activity suspected of causing environmental pollution and/or damage; (7) the right to play a role in environmental protection and management in accordance with statutory regulations; and (8) the right not to be prosecuted, either criminally or civil, in fighting for their rights over the environment. The participatory principle and the principle of openness in the UUPPLH are implemented through providing free space for the community to participate in protecting and managing the environment. ${ }^{3}$ The adoption of these principles in the UUPPLH means that the role

\footnotetext{
${ }^{1}$ Ashabul Kahpi, 'Peran Serta Masyarakat Dalam Pengelolaan Lingkungan Hidup' (2015) 2 Jurisprudentie $<$ https://doi.org/10.24252/jurisprudentie.v2i2.4003\%3E $>$.[42].

2 Widia Edorita, 'Peran Serta Masyarakat Terhadap Lingkungan Menurut UU No. 32 Tahun 2009 Tentang Perlindungan Dan Pengelolaan Lingkungan Hidup' (4AD) 2014 Jurnal Ilmu Hukum Riau.[119].

${ }^{3}$ Martika Dini Syaputri, 'Partisipasi Masyarakat Dalam Penyusunan Analisis Mengenai Dampak Lingkungan Berdasarkan UU NO 32 Tahun 2009’ (2017) 13 Varia Justicia <https://doi. org/10.31603/variajusticia.v13i2.1886>.[123].
} 
of the community to actively participate in protecting and managing the environment is important to achieve the goals of the UUPPLH itself. It does not cover the fact that it is the community that directly feels the impact of the environmental damage and pollution that have had occurred, therefore it is appropriate that the role of the community in fighting for their rights over the environment must be guaranteed with legal certainty.

In general, environmental protection and supervision in the UUPPLH focus on preserving environmental functions and preventing pollution and environmental damage which includes the scope of utilization, planning, maintenance, control, supervision, and law enforcement which are integrated efforts ${ }^{4}$ and are related to each other to achieve the focus which is aimed. Environmental Impact Analysis (hereinafter referred to as Amdal) is one of the instruments to prevent environmental damage and/or pollution within the scope of control of planned activities or businesses that have a significant impact on the environment. The activities or businesses that have a significant impact on the environment are meant to be activities that meet the criteria as referred to in Article 23 UUPPLH. The Amdal document which contains an in-depth analysis of the negative impacts that will be caused by a planned activity or business on the environment ${ }^{5}$ is used as an object of assessment of the planned activity or business to answer whether it is environmentally feasible (meets the criteria for preserving environmental functions) or is not environmentally feasible in the framework of granting a permit (business license). Thus, it can be said that the Amdal document must be the result of an objective scientific analysis (as is) of planned activity or business which includes, among other things: (i) a study of the impact that will be caused; (ii) evaluation of activities around the location of the event; (iii) the response of the affected community to the planned activities; (iv)

\footnotetext{
${ }^{4}$ Risno Mina, 'Desentralisasi Perlindungan Dan Pengelolaan Lingkungan Hidup Sebagai Alternatif Menyelesaikan Permasalahan Lingkungan Hidup' (2016) 9 Arena Hukum <http://dx.doi. org/10.21776/ub.arenahukum.2016.00902.1>.[151].

${ }^{5}$ Nurul Listiyani [et.,al.], 'Penormaan Pengawasan Izin Lingkungan Dalam Pencegahan Pencemaran Dan Kerusakan Lingkungan Hidup Dalam Eksploitasi Sumber Daya Alam’ (2018) 25 Media Hukum < http://journal.umy.ac.id/index.php/jmh/article/view/5420>.[222].
} 
estimates of the magnitude and significance of the impact that will be generated; (v) holistic evaluation of the environmental feasibility of the impact that will be caused; and (vi) environmental management and monitoring plan for the activities to be carried out. Amdal has a very important function in an activity or business that has a significant impact on the environment, which includes in-depth studies from the planning, pre-construction, construction, operation, to post-operation stages. Amdal is not only a requirement for obtaining a permit for activity and/or business ${ }^{6}$ but also serves as a guideline for the implementation of activities to preventing (preventive efforts) from environmental pollution and damage along preserving environmental functions.

The study contained in the Amdal cannot be separated from the participation of the society in providing input and assessment of an activity plan or business that will be carried out. Society is obliged to be involved in the preparation of the Amdal document, which in addition to considering from the perspective of social and economic development, the impacts of the planned activities or business carried out on the preservation of environmental functions are also considered. The regulation of the role of the society in the UUPPLH and its implementing regulations is very important as a legal basis that guarantees the right to be involved in business processes/activities that have a significant impact on the environment. However, in its development, the regulation on society participation in the UUPPLH has undergone several changes with the promulgation of Law Number 11 of 2020 concerning Omnibus Law on Job Creation (hereinafter referred to as UU Cipta Kerja). The society as the party that feels the direct impact of environmental supervision must play an active role in overseeing a government policy related to activities or businesses that have a significant impact on the environment, thus, they can provide social and economic benefits based on the principle of preserving environmental functions. To realize this purpose, it is necessary to guarantee the rights of the community to the environment, one of which is the disclosure of

${ }^{6}$ ibid.[218]. 
environmental information, especially regarding an activity or business that will be or is currently taking place.

Disclosure of environmental information is a right that must be guaranteed by all parties to support the social control function of an activity or business that will be or is being implemented. However, the facts show that there are still many environmental problems arising from the weakness of the supervisory function, both by the competent authorities and the public, of an activity or business that has a significant impact on the environment due to the lack of information disclosure regarding environmental documents related to the activity or business. For example, the problem that has recently occurred is the Benoa Port reclamation activity or project by PT Pelindo III Benoa Branch (hereinafter referred to as Pelindo III) which was submitted as a respondent to the Bali Provincial Information Commission (hereinafter referred to as the Information Commission) in a dispute over public information disclosure by Walhi (Indonesian environmental vehicle) Bali based on the non-response of a written request from Walhi Bali to open several environmental documents related to the project to the public, because it is suspected that the reclamation activities carried out caused the destruction of the mangrove ecosystem covering an area of approximately 17 (seventeen) hectares and the occurrence of several environmental violations. In its application, Walhi Bali requested the opening of several environmental documents related to reclamation activities or projects by Pelindo III, namely, activity location permits, reclamation activity implementation permits, environmental permits, Amdal reference frameworks, and environmental management plan (hereinafter referred to as RKL) matrices and maps and environmental monitoring plans (hereinafter referred to as RPL). ${ }^{7}$ Based on the request, the Information Commission granted Walhi Bali's request with Decision No. 002/V/KEP.KI.BALI/2019 dated 17 May 2019 which decided that Pelindo III was obliged to provide the four requested documents

\footnotetext{
${ }^{7}$ Anton Muhajir, 'Menggugat Keterbukaan Informasi Pelindo III Soal Reklamasi Teluk Benoa' (Mongabay Situs Berita Lingkungan, 2019) <https:/www.mongabay.co.id/2019/01/09/menggugatketerbukaan-informasi-pelindo-iii-soal-reklamasi-teluk-benoa/> accessed 29 October 2019.
} 
along with their attachments in addition to the RKL and RPL matrices and maps. After the issuance of the decision of the Information Commission, Pelindo III was still evasive in opening the requested document, by not providing any related documents (supporting documents), namely the Amdal document as an attachment to the environmental permit. Based on this, Walhi Bali submitted a request for the execution of Decision No. 002/V/KEP.KI.BALI/2019 to the Denpasar District Court, until finally, Pelindo III was then willing to submit the Amdal document as an attachment to the environmental permit for the project. ${ }^{8}$

\section{The Role of Community in Activities that have Significant Impacts on the Environment (Amdal Mandatory)}

The role of the community or generally referred to as community participation is defined as community involvement in a process of planning and implementing policies by the government in which there is a two-way interaction. In this interaction there is an exchange of information between the government and the community regarding the identification of the problems faced (real conditions in the field), their potential, alternative solutions that can be taken, and evaluation of ongoing policies, thus resulting in mutual understanding. The role of the community in the policy-making process is consultative, ${ }^{9}$ thus, input by the community can help the government in formulating a policy to overcoming the problems faced to achieve what is intended. The role of the community can also be described as involving parties who will be affected (negative and/or positive) to participate in influencing the direction and implementation of a policy. Thus, the role of the community is one of the most important factors in influencing the achievement of the objectives of a policy as the implementation of sustainable development. Conyers give a view that

${ }^{8}$ Luh De Suriyani, 'Rumitnya Eksekusi Sengketa Informasi Lingkungan Pertama Di Bali' (Mongabay Situs Berita Lingkungan, 2019) < https://www.mongabay.co.id/2019/10/26/rumitnyaeksekusi-sengketa-informasi-lingkungan-pertama-di-bali/> accessed 29 October 2019.

${ }^{9}$ Lalu Sabardi, 'Peran Serta Masyarakat Dalam Pengelolaan Lingkungan Hidup Menurut Undang-Undang Nomor 32 Tahun 2009 Tentang Perlindungan Dan Pengelolaan Lingkungan Hidup' (2014) 3 Yustisia Jurnal Hukum < https://doi.org/10.20961/yustisia.v3i1.10120>. 
the importance of the role of the community in determining the direction of policy in development can be described as follows: ${ }^{10}$

1. that the role of the community is seen as a tool to obtain information related to real conditions in the field as well as attitudes and behavior of local communities towards the design or implementation of policies, without knowing this, a policy will not be able to solve the problems at hand.

2. that by involving the community in the process of making a development policy, it will make the community more aware of the details of a policy design, therefore, this situation can increase public awareness of development policies which will certainly have an impact on the community itself.

3. that the role of society in engaging in a development policy process is seen as enforcing the principles of a democratic state, namely, from the people, by the people, and for the people.

The role of the community in participating in environmental protection and management can be seen as both a right and an obligation. The recognition of everyone's right to a good and healthy environment as part of human rights in the UUD NRI 1945 has implications for the obligations of all parties in realizing this right. Environmental protection and supervision is a shared responsibility, both the government as the policymaker, the private sector as the initiator of the activity or business, and the community as the party who feels the impact (positive and/or negative) of development. For this reason, good governance principles are needed as the basis for implementing environmental protection and supervision to achieve goals and reduce conflicts in the environmental sector. One of the principles of good governance is the existence of equality in participating in forming a policy that has an impact on the environment, ${ }^{11}$ and the guarantee of this equality must be regulated based on the principle of legal certainty. UUPPLH provides equal opportunities and

\footnotetext{
${ }^{10}$ Diana Conyers, 'Perencanaan Sosial Di Dunia Ketiga' [1991] Gadjah Mada University Press.[154-155];Ashabul Kahpi (n 1).[45].

${ }^{11}$ Kadek Cahya Susila Wibawa, 'Mengembangkan Partisipasi Masyarakat Dalam Perlindungan Dan Pengelolaan Lingkungan Hidup Untuk Pembangunan Berkelanjutan’ (2019) 2 Administrative Law \& Governance Journal < https://doi.org/10.14710/alj.v2i1>.[82].
} 
the widest possible to the public in the form of social supervision, submission of suggestions, suggestions, objections, and delivery of information and/or reports. Thus, the recognition of the right to the environment is a form of guaranteeing the rights of the community in carrying out their responsibilities to take an active role in implementing environmental protection and supervision. ${ }^{12}$

\section{The Role of Community-based on UUPPLH}

The obligation to initiate an activity that has an important impact on the environment to involve the community in the preparation of the Amdal document as stipulated in Article $26 \mathrm{UUPPLH}$ is a translation of the right to access to participation as part of the right to the environment. The exercise of the right to access to participation is based on the principle of transparent and complete disclosure of information, which must be implemented before the activity is carried out (paragraph (2)). ${ }^{13}$ In addition, the implementation of the right to public participation is also based on the principle of equality (an equal position between the initiator of the activity, the community, and the government), the principle of justice and policy (solving problems that are fair and wise), and the principle of coordination and cooperation (participation is carried out by mutual coordination and cooperation between the parties) as regulated in Article 2 of the State Ministry for the Environment Regulation Number 17 of 2012 concerning Guidelines for Community Involvement in the Process of Environmental Impact Analysis and Environmental Permits (hereinafter referred to as Permen LH 17/2012).

UUPPLH and Government Regulation Number 27 of 2012 concerning Environmental Permits (hereinafter referred to as PP Environmental Permits) stipulate that the implementation of community participation in the process of drafting Amdal documents and applications for environmental permits is carried

\footnotetext{
${ }^{12}$ See Article 70 UUPPLH.

${ }^{13}$ Providing transparent and complete information is a must to support the right to public participation, in which the information is provided before the activity is carried out; See Article 26 paragraph (2) UUPPLH.
} 
out in two ways, namely: ${ }^{14}$

1. In the process of drafting the Amdal document, which is carried out by announcing, opinions and responses from the public, submitting suggestions and public consultations as well as participation of representatives of affected communities and/or environmental observer organizations as members of the Amdal Assessment Commission. ${ }^{15}$

2. The application process for an environmental permit, which is carried out by announcing the application for an environmental permit, opinions, and responses from the community, submitting suggestions through their representatives as members of the Amdal Assessment Commission, and announcing the issuance of environmental permits.

Amdal document consists of a Terms of Reference (KA), an Environmental Impact Analysis (Andal), and a RKL-RPL. The Terms of Reference are the results of scoping which contain the scope and depth of the environmental impact assessment. The establishment of the Terms of Reference is preceded by a scoping process, which is a process to determine the scope of the problem and identify the potential impacts (hypotheses) of an activity or business by identifying impacts, evaluating impacts as well as classifications and priorities. ${ }^{16}$ Community involvement is an important part of the scoping process. At this stage, the community is provided with information by announcing the plan for an activity or business. Furthermore, the community is given the opportunity either through public consultations (in the form of workshops, seminars, hearing forums, focus group discussions, etc.) or directly giving written responses, opinions, and suggestions that are conveyed to activity initiators and heads of government in accordance with the scope of authority Amdal assessment (Regent/Mayor within District/City scope, Governor in Provincial scope, or Minister

\footnotetext{
${ }^{14}$ Martika Dini Syaputri (n 3).[125].

${ }^{15}$ The membership of the Amdal Assessment Commission consists of representatives from the affected communities and / or environmental observer organizations; See Article 30 paragraph (1) UUPPLH dan Article 56 paragraph (3) PP Environmental Permits.

${ }^{16}$ Muhamad Erwin, Hukum Lingkungan Dalam Sistem Perlindungan Dan Pengelolaan Lingkungan Hidup Di Indonesia (PT Refika Aditama 2014).[76].
} 
in National scope), where the suggestions, opinions, and responses of the public must be used as input in the preparation of the Terms of Reference document. The input of suggestions, opinions, and responses from the community is carried out by summarizing relevant input as key points to become the attention and consideration of decision-makers, for example, descriptive information related to environmental conditions around the planned activity or business, local community values and local customs, as well as community aspirations regarding planned activities. ${ }^{17}$ After the Terms of Reference have been prepared and declared administratively complete, they will then be assessed by a technical team assigned by the Amdal Assessment Commission (Article 20 PP Environmental Permit).

The Terms of Reference that have been approved and the approval of them are issued are the basis for the preparation of the Andal and RKL-RPL. Reliable is an analysis of the significant impact of an activity plan or business which is carried out by examining carefully and deeply, while RKL is a plan that contains efforts to prevent, control, and cope with significant impacts on the environment as a result of an activity plan or business and RPL is a plan that contains environmental monitoring by measuring environmental components or parameters at regular intervals to determine environmental changes that occur as a result of activities or businesses and to determine the extent to which environmental control has been effective. ${ }^{18}$ In terms of the formulation of the Andal and RKL-RLP, the role of the community can be said to be passive, namely through its representatives as an element of the Amdal Assessment Commission which has the authority to assign a technical team to assess the Andal and RKL-RPL documents.

Based on the results of the Andal and RKL-RPL assessment, the Amdal Assessment Commission issues recommendations for environmental feasibility if the Amdal document is deemed environmentally feasible, by considering: ${ }^{19}$

\footnotetext{
${ }^{17}$ Attachment I to the State Ministry for the Environment Regulation Number 16 of 2002 concerning Guidelines for the Preparation of Environmental Documents.

${ }^{18}$ Muhamad Erwin (n 17). [87-92].

${ }^{19}$ See Article 29 Paragraph (4) PP Environmental Permits.
} 
a. careful estimation of the magnitude and significance of the impact of the activity or business within the bio-geo-physical, chemical, economic, social, cultural, public health, and spatial aspects of the pre-construction, construction, operation, and post-operation stages;

b. a comprehensive evaluation of the hypothetical significant impacts to determine the positive and negative characteristics of the significant impacts caused;

c. the ability to be accountable to the initiating party in overcoming the negative impacts that will arise through technological, social, and institutional approaches.

The recommendations for environmental feasibility are then submitted to the head of government following the scope of authority for the assessment of Amdal to be followed up by issuing an Environmental Feasibility Decree which includes, among other things: (i) the basis for the consideration of the decision on environmental feasibility; (ii) a statement of environmental feasibility of the related activity or business; (iii) requirements and obligations that the initiator must comply with in carrying out activities or business following the RKL-RLP documents; and (iv) the obligations of related parties to be responsible for significant negative impacts that will arise from the activity or business.

The preparation of an Amdal is aimed at obtaining an environmental permit for an activity or business that has an important impact on the environment. An environmental permit is a mandatory requirement to obtain an activity or business license in the framework of environmental protection and management. Amdal and environmental permits as a form of licensing have a directive function, namely as development directors in realizing sustainable development. ${ }^{20}$ The environmental permit contains, among others: ${ }^{21}$ (i) obligations and requirements contained in the Decree of Environmental Feasibility; (ii) the obligations and requirements set by the head of government following the scope of the Amdal's authority; and

\footnotetext{
${ }^{20}$ Absori Absori and Nunik Nurhayati, 'Kebijakan Perizinan, Sengketa Lingkungan Hidup Dan Kepentingan Investasi' (2017) 7 Jurnal Jurisprudence $<$ https://doi.org/10.23917/jurisprudence. v7i2.5539>.[99].

${ }^{21}$ See Article 48 Paragraph (1) PP Environmental Permits.
} 
(iii) license expiration. The application for an environmental permit is submitted together with the application for an Andal and RKP-RPL (Amdal document) assessment to be followed up with an announcement via multimedia and a notice board at the location of the activity. Upon the announcement of the application for an environmental permit, the public is given the opportunity to provide comments and opinions and suggestions through their representatives who are members of the Amdal Assessment Commission within 10 working days of the announcement. Issuance of environmental permits is carried out simultaneously with the issuance of an Environmental Feasibility Decree. environmental permits that have been issued must be announced through multimedia and mass media. UUPPLH emphasizes that, if the initiator as the person in charge of the activity does not carry out the obligations and conditions contained in the Amdal document, the environmental permit that has been issued can be canceled. In addition, environmental permit debates can also be carried out through a State Administrative Court Decision based on a lawsuit filed by the community, where the cancellation is an effort made to prevent wider and bigger environmental damage.

\section{The Role of Society After the Enactment of UU Cipta Kerja}

The Job Creation Law was formed, with the spirit of creating a harmonization of the licensing system in Indonesia to increase investor interest in investing, so that it is hoped that it can boost the pace of the Indonesian economy. Through the Job Creation Law, the licensing system is simplified and harmonized by applying the Business Licensing concept which is carried out by changing, deleting, and/or replacing various laws, one of which is the UUPPLH. The thing of concern in the amendment of the UUPPLH is the elimination of the concept of an Environmental Permit and replaced with the concept of Environmental Approval, which is a Decree of Environmental Feasibility or a statement of Environmental Supervision Capability that has received approval from the Central or Regional Government. The Environmental Approval is a condition for the issuance of Business Licensing. 
These changes also have implications for the provisions regarding the role of the community in the preparation of the Amdal document. Article 22 point 5 of UU Cipta Kerja, which changes the provisions of Article 26, emphasizes that community involvement in the preparation of Amdal documents only involves people who are directly affected by planned activities and/or businesses, in which environmental observers are not involved. This may imply that the process of drafting an Amdal does not involve the community at large, but only the people who are affected. Broadly speaking, the role of the community in the preparation of the Amdal document remains mandatory, so that it does not diminish the essence of community involvement in the process and pre-construction of an activity or business that has a significant impact on the environment.

In principle, the community's role in activities or businesses that have a significant impact on the environment is not limited to the planning and preconstruction stages which include the process of drafting Amdal documents and applications for environmental permits or environmental approvals, but also in the construction, operation and post-operation stages of activities. Article 70 UUPPLH has confirmed that the public has the widest right to play an active role in environmental protection and management by conducting social supervision, providing suggestions, suggestions, making objections and complaints, and submitting information or reports on an activity or business that has an impact on the environment. Supervision is a form of community role that is very important in the construction and operation stages of an activity or business to ensure that the implementation of these activities is in accordance with the license, in the framework of environmental protection and management.

\section{Disclosure of Information on Environmental Documents in Supporting the Role of Community Monitoring}

The public information disclosure dispute case that was requested by Walhi Bali to open several environmental documents related to the Benoa Port reclamation activity or project carried out by Pelindo III is an example of 
a real situation in the field related to the difficulty of obtaining environmental document information on an activity or business that has an important impact. to the environment. Disclosure of public information as a form of guaranteeing human rights as mandated by Article 28F of UUD NRI 1945 and the principles of good governance 22 is an effort to optimize the role of public oversight of government policies as state administrators that have an impact on the interests of the community itself. ${ }^{23}$ The right to public information includes the right to view and know public information and the right to obtain a copy of public information in accordance with statutory regulations.

In simple terms, public information can be interpreted as all information relating to the public or public interest. Concerning environmental protection and supervision, disclosure of information on environmental documents is understood as the right to public information, because the responsibility to maintain environmental functions is in the interests of the community in fulfilling human rights to the environment. I Gede Agus Astapa as Chairperson of the Bali Information Commission Session Council in the case of the dispute over the disclosure of public information on the Benoa Port reclamation project explained that information on environmental documents such as environmental permits and Amdal clearly includes public information that must be provided and announced as regulated in Articles 9 to 11 of the UUKIP. ${ }^{24}$ Article 11 paragraph (1) letter c of UUKIP regulates that public information that must be provided at any time by public bodies is all policies issued along with supporting documents. Concerning these provisions, an environmental permit can be interpreted as a policy issued by a public body in accordance with the scope of its authority over activity or business that has a significant impact on the environment as a form of control to prevent and control negative impacts of

\footnotetext{
${ }^{22}$ Komarudin Komarudin and Heru Dwi Wahjono, 'Implikasi Undang-Undang No. 14 Tahun 2008 Tentang Keterbukaan Informasi Publik Pada Informasi Teknologi Pengelolaan Air Bersih Dan Limbah Cair' (2008) 4 Jurnal Air Indonesia <http://dx.doi.org/10.29122/jai.v4i2.2425>.[173].

${ }^{23}$ See the Preamble to Consider Law Number 14 of 2008 concerning Freedom of Information (hereinafter referred to as UUKIP).

${ }^{24}$ Anton Muhajir (n 7).
} 
activities on the environment ${ }^{25}$ with terms and obligations that must be obeyed and fulfilled by the person in charge of activities according to the Amdal document as a supporting document for the environmental permit.

Environmental permits (including supporting documents) as a form of permit issued by government officials require supervision as a form of control and prevention of negative impacts on the environment arising from an activity or business. Issuance of environmental permits is carried out with the conditions and obligations that must be obeyed by the person in charge of an activity or business that has a permit, thus supervision as a form of control and legal action against violations by the competent official is a must. ${ }^{26}$ These terms and obligations are the results of an in-depth analysis contained in the Amdal document which contains procedures and governance for the implementation of an activity as an effort to minimize environmental damage and pollution as well as monitoring procedures as a measure of the effectiveness of these procedures and governance by measuring changes environment that occurs as a result of activities.

In terms of supervision, the UUPPLH regulates that government officials within the scope of their authority are obliged to supervise the person in charge of an activity or business for compliance with environmental permits. ${ }^{27}$ The supervision is carried out to answer two things, namely (i) whether the activity or business has an environmental permit; and (ii) whether the implementation of the activity or business complies with the terms and obligations contained in the environmental permit. However, the less optimal role of supervision by authorized officials has resulted in a lot of environmental damage and pollution that occurs as a result of violations of environmental law, such as non-compliance with the terms and obligations contained in an environmental permit or even running activities or businesses without pocketing an environmental permit illegal). Similar to

\footnotetext{
${ }^{25}$ Andri Gunawan Wibisana, 'Pengelolaan Lingkungan Melalui Izin Terintegrasi Dan Berantai: Sebuah Perbandingan Atas Perizinan Lingkungan Di Berbagai Negara' (2018) 48 Jurnal Hukum \& Pembangunan <http://dx.doi.org/10.21143/jhp.vol48.no2.1662>. [224].

${ }^{26}$ Martika Dini Syaputri (n 3).[126].

${ }^{27}$ See Article $71 \& 72$ UUPPLH
} 
the process of issuing environmental permits as a policy, the role of community oversight is no less important. The UUPPLH has provided the widest possible right and opportunity for the community to participate in social monitoring as an implementation of the right to access to participation.

The role of community supervision of activities or businesses that have an important impact on the environment must be supported by the disclosure of information on environmental documents, especially Amdal documents which contain detailed information on the implementation of activities or businesses in accordance with the principle of preserving environmental functions. The disclosure of the information is based on the principles of fast and timely, low cost, and simple, meaning that access to environmental information must reflect simple procedures that make it easy and obtain proportional costs according to general standards. Disclosure of information on environmental documents is a fundamental right of the community in order to take part in overseeing sustainable development in their area of residence. The easy access of the public to obtain information related to environmental documents on activities or businesses that have a significant impact on the environment makes the role of community social supervision run optimally. The community will find it very easy to find detailed information on an activity or business that is currently running both in the construction and operation stages so that they can ascertain whether the activity has an environmental permit or whether the executor of the activity has complied with the terms and obligations contained in environmental documents in the context of protection and supervision of the environment.

\section{Conclusion}

The role of the community in activities or businesses that have a significant impact on the environment is not limited to activity plans which include the planning and preconstruction phases of activities carried out with public consultations and the delivery of suggestions, suggestions, opinions, and responses. but also in the implementation of activities including the construction stage, the operation of activities carried out with social supervision, objections, and complaints. The role 
of community supervision must be optimized with the disclosure of information on environmental documents as a guideline for detailed information regarding compliance with the implementation of activities by the person in charge of the requirements and obligations that must be fulfilled in order to protect and manage the environment based on the principle of preserving environmental functions. For this reason, disclosure of information on environmental documents must be seen as the implementation of the right to information as part of the right to the environment in supporting the implementation of community responsibilities in striving to guarantee and fulfill the rights of everyone to a good and healthy environment as human rights, so that an activity or business which is illegal and/or violates environmental permits that cause environmental damage and pollution can be controlled and prevented.

\section{Bibliography}

Absori Absori and Nunik Nurhayati, 'Kebijakan Perizinan, Sengketa Lingkungan Hidup Dan Kepentingan Investasi' (2017) 7 Jurnal Jurisprudence $<$ https:// doi.org/10.23917/jurisprudence.v7i2.5539>.

Andri Gunawan Wibisana, 'Pengelolaan Lingkungan Melalui Izin Terintegrasi Dan Berantai: Sebuah Perbandingan Atas Perizinan Lingkungan Di Berbagai Negara' (2018) 48 Jurnal Hukum \& Pembangunan $<$ http://dx.doi. org/10.21143/jhp.vol48.no2.1662>.

Anton Muhajir, 'Menggugat Keterbukaan Informasi Pelindo III Soal Reklamasi Teluk Benoa' (Mongabay Situs Berita Lingkungan, 2019) <https://www. mongabay.co.id/2019/01/09/menggugat-keterbukaan-informasi-pelindo-iiisoal-reklamasi-teluk-benoa/> accessed 29 October 2019.

Ashabul Kahpi, 'Peran Serta Masyarakat Dalam Pengelolaan Lingkungan Hidup' (2015) 2 Jurisprudentie <https://doi.org/10.24252/jurisprudentie. v2i $2.4003 \% 3 \mathrm{E}>$.

Diana Conyers, 'Perencanaan Sosial Di Dunia Ketiga' [1991] Gadjah Mada University Press.

Kadek Cahya Susila Wibawa, 'Mengembangkan Partisipasi Masyarakat Dalam Perlindungan Dan Pengelolaan Lingkungan Hidup Untuk Pembangunan Berkelanjutan' (2019) 2 Administrative Law \& Governance Journal <https:// 
doi.org/10.14710/alj.v2i1>.

Komarudin Komarudin and Heru Dwi Wahjono, 'Implikasi Undang-Undang No. 14 Tahun 2008 Tentang Keterbukaan Informasi Publik Pada Informasi Teknologi Pengelolaan Air Bersih Dan Limbah Cair' (2008) 4 Jurnal Air Indonesia <http://dx.doi.org/10.29122/jai.v4i2.2425>.

Lalu Sabardi, 'Peran Serta Masyarakat Dalam Pengelolaan Lingkungan Hidup Menurut Undang-Undang Nomor 32 Tahun 2009 Tentang Perlindungan Dan Pengelolaan Lingkungan Hidup' (2014) 3 Yustisia Jurnal Hukum $<$ https://doi. org/10.20961/yustisia.v3i1.10120>.

Luh De Suriyani, 'Rumitnya Eksekusi Sengketa Informasi Lingkungan Pertama Di Bali' (Mongabay Situs Berita Lingkungan, 2019) <https://www.mongabay. co.id/2019/10/26/rumitnya-eksekusi-sengketa-informasi-lingkunganpertama-di-bali/> accessed 29 October 2019.

Martika Dini Syaputri, 'Partisipasi Masyarakat Dalam Penyusunan Analisis Mengenai Dampak Lingkungan Berdasarkan UU NO 32 Tahun 2009’ (2017) 13 Varia Justicia <https://doi.org/10.31603/variajusticia.v13i2.1886>

Muhamad Erwin, Hukum Lingkungan Dalam Sistem Perlindungan Dan Pengelolaan Lingkungan Hidup Di Indonesia (PT Refika Aditama 2014).

Nurul Listiyani, [et.,al.], 'Penormaan Pengawasan Izin Lingkungan Dalam Pencegahan Pencemaran Dan Kerusakan Lingkungan Hidup Dalam Eksploitasi Sumber Daya Alam' (2018) 25 Media Hukum <http://journal. umy.ac.id/index.php/jmh/article/view/5420>.

Risno Mina, 'Desentralisasi Perlindungan Dan Pengelolaan Lingkungan Hidup Sebagai Alternatif Menyelesaikan Permasalahan Lingkungan Hidup' (2016) 9 Arena Hukum <http://dx.doi.org/10.21776/ub.arenahukum.2016.00902.1>.

Widia Edorita, 'Peran Serta Masyarakat Terhadap Lingkungan Menurut UU No. 32 Tahun 2009 Tentang Perlindungan Dan Pengelolaan Lingkungan Hidup' (4AD) 2014 Jurnal Ilmu Hukum Riau.

HOW TO CITE: I Made Gemet Dananjaya Suta, I Gusti Agung Mas Prabandari and Ni Luh Gede Astariyani, 'Disclosure of Information on Environmental Documents in Supporting the Role of Public Monitoring' (2021) 36 Yuridika. 
I Made Gemet: Disclosure of Information on Environmental

--This page is intentionally left blank-- 